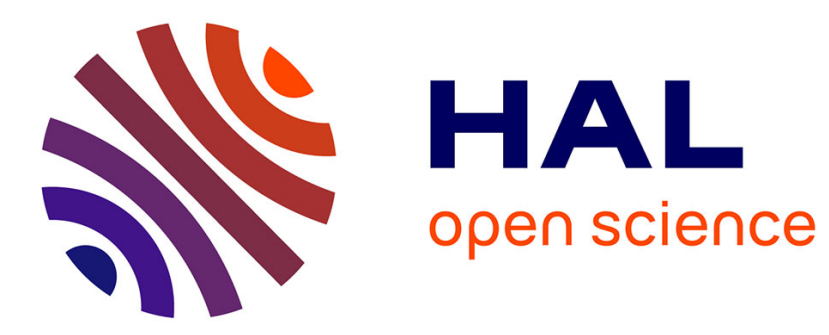

\title{
Origin and distribution of rare earth elements in various lichen and moss species over the last century in France
}

\author{
Yannick Agnan, Nathalie Séjalon-Delmas, Anne Probst
}

\section{To cite this version:}

Yannick Agnan, Nathalie Séjalon-Delmas, Anne Probst. Origin and distribution of rare earth elements in various lichen and moss species over the last century in France. Science of the Total Environment, 2014, vol. 487, pp. 1-12. 10.1016/j.scitotenv.2014.03.132 . hal-01015842

\section{HAL Id: hal-01015842 \\ https://hal.science/hal-01015842}

Submitted on 27 Jun 2014

HAL is a multi-disciplinary open access archive for the deposit and dissemination of scientific research documents, whether they are published or not. The documents may come from teaching and research institutions in France or abroad, or from public or private research centers.
L'archive ouverte pluridisciplinaire HAL, est destinée au dépôt et à la diffusion de documents scientifiques de niveau recherche, publiés ou non, émanant des établissements d'enseignement et de recherche français ou étrangers, des laboratoires publics ou privés. 


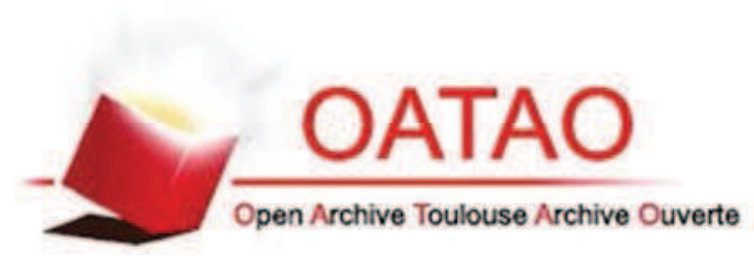

\section{Open Archive TOULOUSE Archive Ouverte (OATAO)}

OATAO is an open access repository that collects the work of Toulouse researchers and makes it freely available over the web where possible.

This is an author-deposited version published in : http://oatao.univ-toulouse.fr/ Eprints ID : 11726

To link to this article : DOI:10.1016/j.scitotenv.2014.03.132

URL : http://dx.doi.org/10.1016/j.scitotenv.2014.03.132

To cite this version : Agnan, Yannick and Séjalon-Delmas, Nathalie and Probst, Anne Origin and distribution of rare earth elements in various lichen and moss species over the last century in France. (2014) Science of the Total Environment, vol. 487 . pp. 1-12. ISSN 0048-9697

Any correspondance concerning this service should be sent to the repository administrator: staff-oatao@,listes-diff.inp-toulouse.fr 


\title{
Origin and distribution of rare earth elements in various lichen and moss species over the last century in France
}

\author{
Y. Agnan ${ }^{\mathrm{a}, \mathrm{b}}$, N. Séjalon-Delmas ${ }^{\mathrm{a}, \mathrm{b}}$, A. Probst ${ }^{\mathrm{a}, \mathrm{b}, *}$ \\ a Université de Toulouse; INP, UPS; EcoLab (Laboratoire Ecologie Fonctionnelle et Environnement); ENSAT, Avenue de l'Agrobiopole, F-31326 Castanet-Tolosan, France \\ b CNRS; EcoLab; F-31326 Castanet-Tolosan, France
}

\section{H I G H L I G H T S}

- Rare earth were explored in current and herbarium lichens and mosses in France.

- Rare earth patterns indicated a lithogenic origin from weathering of regional bedrock.

- Herbarium data showed a converging regional influence over one century (1870-2010).

- Bark substrate had no influence on REE content.

- For timescale comparison, normalization was recommended instead of concentrations.

\section{Keywords: \\ REE \\ Anomalies \\ Lichens \\ Mosses \\ Herbarium \\ Bark \\ Bedrock}

\begin{abstract}
A B S T R A C T
Rare earth elements (REE) are known to be powerful environmental tracers in natural biogeochemical compartments. In this study, the atmospheric deposition of REE was investigated using various lichens and mosses as well as herbarium samples from 1870 to 1998 from six major forested areas in France. The comparison between the REE distribution patterns in organisms and bedrocks showed a regional uniformity influence from dust particles originating from the bedrock and/or soil weathering that were entrapped by lichens and mosses. These lithological signatures were consistent over the last century. The REE patterns of different organism species allowed minor influence of the species to be highlighted compared to the regional lithology. This was even true where the morphological features played a role in the bioaccumulation levels, which were related to the variable efficiency in trapping atmospheric dust particles. A comparison between REE profiles in the organisms and bark indicated a lack of influence of the substrate on lichen REE content. Lichens and mosses appear to be robust passive monitors of REE atmospheric deposition over decades because the mineral data was preserved in herbarium samples despite organic degradation being shown by carbon isotopes and SEM observations. To overcome the bias of REE concentration that resulted from organic degradation, the use of a normalized method is recommended to interpret the historical samples.
\end{abstract}

\section{Introduction}

Natural and anthropogenic emissions contribute to the enrichment of atmospheric trace element content (Rauch and Pacyna, 2009) and lead to local/regional or long-range atmospheric deposition (Rosman et al., 1994; Wolff et al., 1999). The atmospheric deposition of trace metals is known to affect ecosystem health (Ulrich and Pankrath, 1983). Therefore, to ensure the protection of ecosystems, the contribution of these atmospheric elements on land surfaces must be assessed (Nilsson and Grennfelt, 1988). Direct tentative evaluations of metal

\footnotetext{
* Corresponding author at: CNRS; EcoLab; F-31326 Castanet-Tolosan, France. Tel.: + 33 5343239 42; fax: + 33534323955.

E-mail address: anne.probst@ensat.fr (A. Probst).
}

deposition by instrumental measurement have been performed (Azimi et al., 2003; Gandois et al., 2010a; Garnaud et al., 1999); however, the process is complex and expensive. Thus, biological monitoring has been developed over the past 30 years (Hawksworth and Rose, 1970; Swieboda and Kalemba, 1978) and has proven to be a good alternative tool (Loppi et al., 1997; Markert et al., 2003; Harmens et al., 2010), particularly in the spatial evaluation of atmospheric deposition. Lichens and mosses are known to be sensitive to atmospheric contaminants because of their biological features (Conti and Cecchetti, 2001; Wolterbeek, 2002) that make them susceptible to accumulating trace metals from the atmosphere (Rühling and Tyler, 1968; Loppi et al., 1997). A major challenge remains in assessing the contribution of natural versus anthropogenic inputs of metals to ecosystems. Among the trace metals, geochemical tracers such as rare earth elements (REE) 
have been demonstrated to be powerful tools to characterize the origin of these accumulated elements (Carignan and Gariepy, 1995; Chiarenzelli et al., 2001).

The chemical family of REE (also called lanthanides) includes 14 natural trace metallic components from La to Lu, which excludes Pm (non-naturally occurring in a stable form); although some authors include Sc and Y as well (Ichihashi et al., 1992; Pang et al., 2002). These elements have robust chemical characteristics, such as the same electronic structure, oxidation state and electronegativity (Henderson, 1984). REE can be subdivided into three groups: light rare earth elements (LREE) from La to Nd, medium rare earth elements (MREE) from Sm to Dy and heavy rare earth elements (HREE) from Ho to Lu. Despite their physicochemical similarities, LREE are more soluble and less able to form complexes than HREE (Goldschmidt, 1937; Henderson, 1984; Cantrell and Byrne, 1987) and Ce and Eu are characterized by double oxidation states $\left(\mathrm{Ce}^{3+} / \mathrm{Ce}^{4+}\right.$ and $\left.\mathrm{Eu}^{2+} / \mathrm{Eu}^{3+}\right)$. The REE groups are used as tracers in various geochemical fields such as the surface geochemistry (Tricca et al., 1999; Aubert et al., 2001; Laveuf and Cornu, 2009), or the geology of the earth or moon (Weill and Drake, 1973; Taylor, 1982; Gromet and Silver, 1983).

Particularly, REE distribution patterns using lichen content analysis have been demonstrated as efficient in determining the origin of metals compared to bulk precipitation or local lithology (Chiarenzelli et al., 2001; Aubert et al., 2002, 2006; Rusu et al., 2006; Spickova et al., 2010). Recently, Agnan et al. (2013) emphasized the lithologic influence on lichen metal content in the southwest of France. Nevertheless, literature investigations are often focused on a single area or one specific region, although different compartments (lichens, mosses, bark, soil or deposition) are considered when accounting for REE behavior (Markert and de Li, 1991; Rusu et al., 2006; Spickova et al., 2010). REE investigations that consider various sites on a national scale remain scarce, particularly when considering the entire REE pattern. Indeed, few studies have considered the geochemical signatures, such as REE anomalies, to characterize the origin of these elements. The influences of various environmental parameters are poorly documented. Only Chiarenzelli et al. (2001) have sought to characterize the role of the substrate using the terricolous lichen species Cladonia when considering species influence. Furthermore, few historical data on REE are available (peat and soil archives). The REE registered in lichens and mosses on a century scale are rare; however, Agnan et al. (2013) have shown that they could bring interesting comparisons between past and present lichen samples.

In this study, we attempted to determine the concentration levels, distribution patterns and geochemical anomalies of REE accumulated in several species of corticolous lichens and mosses from various regions of France (and neighboring countries) using present-day and historical samples. There were a number of objectives: (i) evaluate the levels of accumulated REE in organisms collected in the two periods in different areas of the country, (ii) assess the temporal evolution of bioaccumulated REE by comparing standardized patterns in current and herbarium samples, (iii) determine the respective influence of lithological erosion sources and tree bark substrates on bioaccumulated REE by comparing the REE distribution patterns in regional bedrock and tree bark, and (iv) evaluate the organism species influence on REE bioaccumulation using six lichen and three moss species.

\section{Materials and methods}

\subsection{Study area and collected species}

This study used 218 samples, including 6 lichen species with 3 foliose lichens (Hypogymnia physodes (L.) Nyl., Parmelia sulcata Taylor (and in some stations Flavoparmelia caperata (L.) Hale, Parmelina tiliacea (Hoffm.) Hale, Punctelia borreri (Sm.) Krog and Hypotrachyna revoluta (Flörke) Hale when P. sulcata was absent) and Xanthoria parietina (L.) Th. Fr.) and 3 fruticose lichens (Evernia prunastri (L.) Ach., Pseudevernia

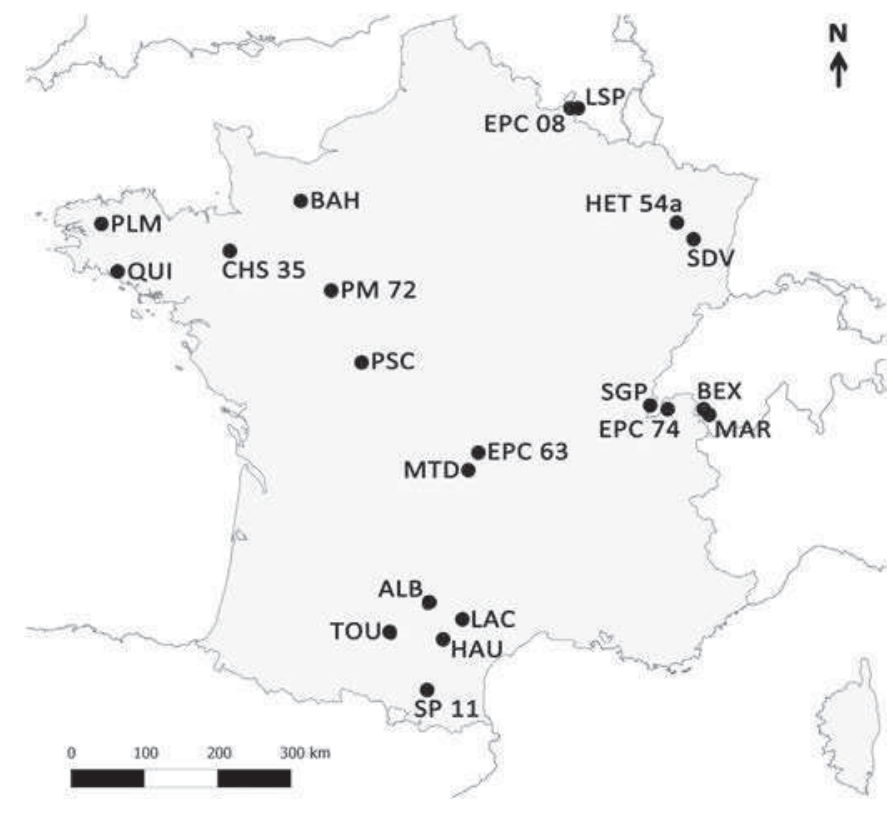

Fig. 1. Studied area with the 21 sampling sites in various regions of France and neighboring countries.

furfuracea (L.) Zopf., Usnea sp.) and 3 moss species (Hypnum cupressiforme Hedw., Pleurozium schreberi (Brid.) Mitt., Scleropodium purum (Hedw.) Limpr.). The samples were obtained from 21 sites located in various regions of France and neighboring countries (Belgium and Switzerland) in forested conditions (pine, fir, spruce, oak and beech) far from any source of contamination (Fig. 1). The site selection was conditioned by the presence of herbarium samples and different environmental contexts from various regions of France: the western region has an oceanic climate; Massif Central, Vosges and Ardennes areas have a semi-continental climate, and Alps and Pyrenean Mountains have a mixed mountain and semi-continental climate. This study included seven sites from the French monitoring network of forest ecosystems RENECOFOR (Réseau National de suivi des Écosystèmes Forestiers: SP 11, EPC 63, EPC 74, HET 54a, EPC 08, PM 72 and CHS 35) that belong to the International Co-operative Programme (ICP) forest network; these sites have previously been investigated for atmospheric metal contamination (Gandois et al., 2010b; Hernandez et al., 2003). The sites (Table 1a) exhibited a wide regional diversity of lithology from sedimentary (alluvium, limestone, sandstone) to magmatic rocks (e.g., granite, basalt or schist). The samples included 25 herbarium specimens collected between 1870 and 1998 with 14 different species from 6 herbaria belonging to the University of Toulouse (Index Herbariorum: $\mathrm{TL}$ ) and a 1998 sample from Geneva (a gift from the French lichenologist Mr. Sussey). All of the details regarding the herbarium specimens are presented in Table 1b. The locations mentioned in the herbarium specimen labels were used to facilitate the current sampling at the same sites.

\subsection{Sampling procedure}

As described in Agnan et al. (2013), the present-day sampling considered an area of approximately $25,000 \mathrm{~m}^{2}$ and included 3-5 homogeneous sub-areas that were represented by a single data value from several tens of thalli with a diameter greater than $2 \mathrm{~cm}$, which indicated an age and integration period of atmospheric deposition of several years or decades. With the exception of the Saint-Dié-des-Vosges stations (terricolous mosses), the sampling was performed on all sides of the tree trunks to reduce the influence of micrometeorological parameters 
Table 1

Description of sampling locations: a. for current samples and b. for herbarium samples (Ep: Evernia prunastri, Hc: Hypnum cupressiforme, Hp: Hypogymnia physodes, Pf: Pseudevernia furfuracea, Ps: Parmelia sulcata, Psc: Pleurozium schreberi, Sp: Scleropodium purum, U: Usnea sp., Xp: Xanthoria parietina).

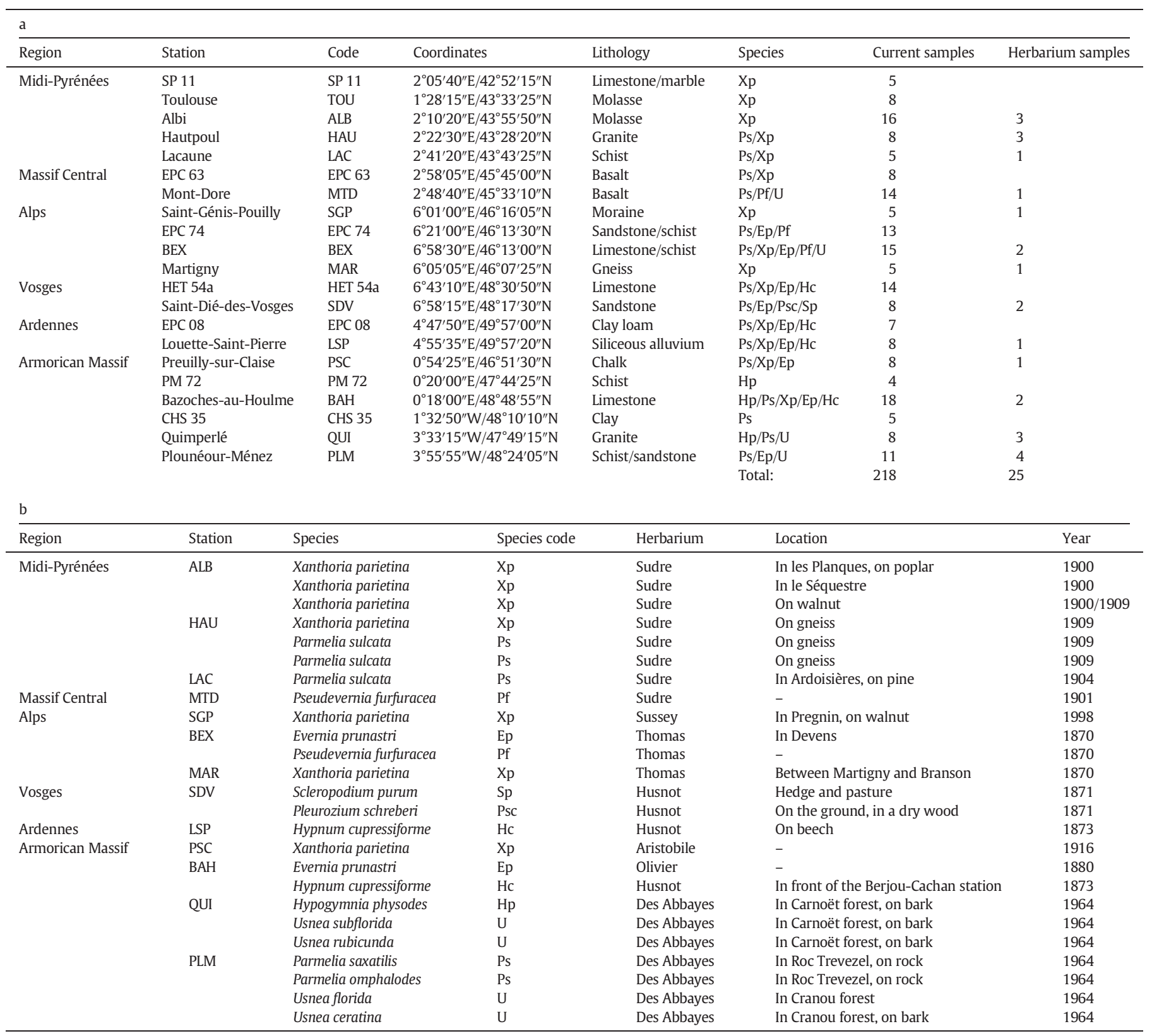

(wind direction, exposition, light, temperature, humidity, intensity of precipitations, etc.) and obtain a representative sampling of the lichen growing in a given site. The specimens were collected from tree trunks at a height of approximately $1.5 \mathrm{~m}$ to prevent potential contamination by splashing of soil particles during rainfall using a ceramic knife and latex gloves to avoid any metal contamination (Bargagli and Nimis, 2002). Various species of trees were included to limit the potential influence of substrate species on metal content (De Bruin and Hackenitz, 1986; Markert and de Li, 1991; Prussia and Killingbeck, 1991). The objectives of this protocol were to restrict the intra-variability at each station and increase the representativeness of each studied area (Agnan et al., 2013), although the age of analyzed thalli may have caused concentration variability (Garty, 2001). Dry lichen and moss samples were kept in plastic bags prior to processing in preparation for the experiments.
The historical samples were extracted from the herbarium sheets with the same caution as described above. Particular care was taken to avoid the parts of the samples that may have been in contact with glue.

In parallel to the current sampling of lichens, the bark of ash (Fraxinus excelsior L.) was collected at three sites (ALB, EPC 63 and PSC) close to the lichens and with the same protocols as described above for lichens. Only the first $2 \mathrm{~cm}$ of bark depth was considered.

\subsection{Pre-analysis treatments and analytical procedure}

After sampling, a portion of the chosen species (lichens and mosses) was selected in the lab before drying at $30^{\circ} \mathrm{C}$. To avoid losing particles trapped on the surface (Richardson, 1992; Bergamaschi et al., 2007) the unwashed samples were ground in an agate mortar with liquid 
nitrogen, and the powdered samples were stored carefully in a plastic tube until treatment.

The lichen and moss samples were digested in a cleanroom ISO 7 at the Laboratoire écologie fonctionnelle et environnement (EcoLab, Toulouse, France) using a mixture of suprapure acids $\left(\mathrm{HNO}_{3}\right.$ and $\mathrm{HF}$, Fisher), $\mathrm{H}_{2} \mathrm{O}_{2}$ (Fisher) and high-purity water $(18.2 \mathrm{M} \Omega \mathrm{cm})$ to evaluate the total accumulation/deposition (Rusu, 2002). Following the procedure described in Agnan et al. (2013), a sample of approximately $100 \mathrm{mg}$ of powder was digested using $0.5 \mathrm{~mL}$ of $68 \% \mathrm{HNO}_{3}$ and $0.5 \mathrm{~mL}$ of $50 \% \mathrm{HF}$ at $90{ }^{\circ} \mathrm{C}$ in a teflon container for $48 \mathrm{~h}$. After evaporation, $1 \mathrm{~mL}$ of $\mathrm{H}_{2} \mathrm{O}_{2}$ was added and evaporated at $50{ }^{\circ} \mathrm{C}$. The final mineralization step was performed after the addition of $1 \mathrm{~mL}$ of $68 \% \mathrm{HNO}_{3}$ for $48 \mathrm{~h}$ at $90{ }^{\circ} \mathrm{C}$. Finally, the samples were diluted by 1200 times to obtain $2 \% \mathrm{HNO}_{3}$ solutions before the spectrometric analysis. For each series, two replicates of certified lichen materials (lichen IAEA-336) were added to evaluate the performance of the procedure. The blank sample analysis $(<1 \%$ of the sample concentrations) indicates an absence of contamination during the digestion procedure.

The REE (La, Ce, Pr, Nd, Sm, Eu, Gd, Tb, Dy, Ho, Er, Tm, Yb and Lu) were analyzed using ICP-MS analytical platforms ICP-QMS Agilent Technologies 7500 CE and HR-ICP-MS Thermo Scientific Element XR at the OMP (Observatoire Midi-Pyrénées, Toulouse, France) and ICP-QMS Thermo Scientific Element X-II (laboratory HSM, HydroSciences Montpellier, France). Terbium was not analyzed for the Vosges, Ardennes and Armorican Massif regions because of its absence in the internal standard used. The detection limits were $<50 \mathrm{pg} \mathrm{g}^{-1}$.

During the ICP-MS analysis, ${ }^{115} \mathrm{In} /{ }^{187} \mathrm{Re}$ internal standards of a known concentration were added to all of the samples and four quality control samples were introduced following every eight samples to correct for any analyzer deviation. The average recovery $\left(\mathrm{C}_{\text {measured }} /\right.$ $\mathrm{C}_{\text {certified }} * 100$ ) calculated using the lichen IAEA-336 for each analyte was approximately $82 \%$ : $90 \%$ to $100 \%$ for $\mathrm{Sm}$ and $\mathrm{Eu}, 80 \%$ to $90 \%$ for $\mathrm{Ce}, \mathrm{Nd}, \mathrm{Tb}$ and $\mathrm{Yb}$ and $70 \%$ to $80 \%$ for $\mathrm{La}, \mathrm{Tm}$ and $\mathrm{Lu}$.

Carbon analyses were performed to characterize the organic matter of 20 current and 20 historical lichen samples. The total carbon concentrations were measured by gas chromatography (IsoPrime vario Micro cube, EcoLab, Toulouse, France) of $\mathrm{CO}_{2}$ that resulted from the combustion $\left(>1,200^{\circ} \mathrm{C}\right)$ of $0.5-0.8 \mathrm{mg}$ powder samples introduced in a tin capsule. The carbon isotopic analysis was performed by mass spectrometry (IsoPrime 100 IRMS, EcoLab, Toulouse, France). Data were normalized using internal standards (Pee Dee Belemnite). The $\sigma$ analytical precision was $\pm 0.15 \%$ for $\delta^{13} \mathrm{C}$.

In parallel to these analyses, scanning electron microscopy (SEM) observations of the current and historical samples were conducted using a FEI ESEM Quanta 250 FEG (CMEAB, Toulouse, France). One current and one historical $X$. parietina sample was observed with a secondary electron detector in high vacuum $\left(2.65 \cdot 10^{-3} \mathrm{~Pa}, 5 \mathrm{kV}\right)$ and low vacuum (161 Pa, $10 \mathrm{kV}$ ) mode, respectively.

\subsection{Data treatment}

To remove the Oddo-Harkins effect that affected the REE abundance, the concentrations were normalized to PAAS (Post-Archean Australian Shale) to obtain pattern profiles (Chiarenzelli et al., 2001; Aubert et al., 2002) using data from Taylor and McLennan (1985). PAASnormalized anomalies were calculated by dividing the normalized value by the expected value (noted with an asterisk); the latter was obtained by averaging the values of the elements immediately prior and after (e.g., Sm and Gd for Eu).

Statistical treatments were preceded by data normality tests. When the normality did not pass for all of the REE concentration data with the Kolmogorov-Smirnov test, statistical analyses were performed on the standard scores. A principal components analysis (PCA) was performed on this dataset, which was previously normalized by the sum of REE ( REE) using R software.

\section{Results}

\subsection{REE concentration levels, carbon isotopes and SEM observations}

\subsubsection{Current samples}

The REE levels of the current samples $(n=193)$, considering all of the lichen and moss species, indicated the following order of abundance: $\mathrm{Ce}>\mathrm{La}>\mathrm{Nd}>\mathrm{Pr}>\mathrm{Sm}>\mathrm{Gd}>\mathrm{Dy}>\mathrm{Er}>\mathrm{Yb}>\mathrm{Eu}>\mathrm{Tb}>\mathrm{Ho}$ $>\mathrm{Tm}$, Lu (Table 2); this order was found in all of the natural compartments (Taylor and McLennan, 1985). The concentrations were in the same range as those of the lichen samples found in the literature (Markert and de Li, 1991; Spickova et al., 2010). As previously observed by Chiarenzelli et al. (2001), the standard deviations were as high as the mean values. The Midi-Pyrénées region (LAC, TOU, HAU and SP 11) contained lichens with the most enriched REE concentrations (regional mean of $\Sigma$ REE concentration without Tb: $6.68 \pm 0.84 \mu \mathrm{g} \cdot \mathrm{g}^{-1}$ ), whereas the Armorican Massif and Ardennes generally exhibited the lowest concentrations (regional $\Sigma$ REE means: $2.50 \pm 0.31 \mu \mathrm{g} \cdot \mathrm{g}^{-1}$ and $2.93 \pm 0.36 \mu \mathrm{g} \cdot \mathrm{g}^{-1}$, respectively); the samples from the Massif Central, Vosges and Alps showed similar intermediate concentrations (regional ¿REE means: $3.10 \pm 0.40 \mu \mathrm{g} \cdot \mathrm{g}^{-1}, 3.29 \pm 0.41 \mu \mathrm{g} \cdot \mathrm{g}^{-1}$ and $3.31 \pm$ $0.40 \mu \mathrm{g} \cdot \mathrm{g}^{-1}$, respectively) (see Supplementary data). The REE concentrations differed among the groups of organisms and were in the following order based on the $\Sigma$ REE means: fruticose lichens $\left(1.75 \pm 0.72 \mu \mathrm{g} \cdot \mathrm{g}^{-1}, \mathrm{n}=16\right)<$ foliose lichens $\left(4.04 \pm 2.27 \mu \mathrm{g} \cdot \mathrm{g}^{-1}\right.$, $\mathrm{n}=32)<\operatorname{mosses}\left(4.78 \pm 2.54 \mu \mathrm{g} \cdot \mathrm{g}^{-1}, \mathrm{n}=6\right)$. However, concentrations were in the same order of magnitude as those found in the literature (Chiarenzelli et al., 2001; Dolegowska and Migaszewski, 2013). Despite this variability, the REE normalized distribution patterns provided robustness for these elements as well as for the herbarium samples (Agnan et al., 2013).

\subsubsection{Herbarium samples}

The herbarium samples (Table $2, \mathrm{n}=25$ ) had higher mean concentrations than the current samples, and there was a strong variability among the samples (SD exceeded the mean value), which explained the non-significant difference observed between these two groups for the more concentrated REE (Kruskal-Wallis test). The highest values were reached for X. parietina and P. sulcata in HAU (see Supplementary data) for all of the REE, which was previously reported for the trace metal content (Agnan et al., 2013). The historical REE/current REE concentration ratio for a given site was relatively conserved among the elements. For example, it was $26 \pm 4$ for P. sulcata in HAU, $2.3 \pm$ 0.1 for $X$. parietina in PSC, and $4.7 \pm 0.3$ for $H$. physodes in QUI.

To evaluate the organism integrity over time, carbon isotope measurements and SEM observations were performed on the herbarium and current lichens. Carbon isotope $\delta^{13} \mathrm{C}$ data (Fig. 2) of the current lichens from ten stations $(-23.94 \pm 1.05 \%, \mathrm{n}=10)$ were comparable to the literature data of German samples (Beck and Mayr, 2012), whereas the historical samples were less negative $(-20.46 \pm 1.07 \%, n=10)$. Data from these two groups were significantly different ( $<<0.001$, t-test, $\alpha=0.05$ ), and the SEM observations of both current (2012) and herbarium (1916) samples of X. parietina from PSC (Fig. 3) indicated a more condensed structure (55-60 $\mu \mathrm{m}$ versus $42-50 \mu \mathrm{m}$ thick, respectively) with a loss of algal cells in the 1916 sample.

\subsection{REE distribution patterns}

\subsubsection{REE patterns in current samples}

Fig. 4 shows the PAAS-normalized distribution patterns of the REE profiles in lichens and mosses from the different regions. All of the profiles were depleted 14 to 350 times compared to the PAAS, and they exhibited a similar global trend with a relative MREE enrichment ( mean of $\mathrm{Gd}_{\mathrm{N}} / \mathrm{La}_{\mathrm{N}}=1.20 \pm 0.15$ ), a more pronounced HREE depletion (mean of $\mathrm{La}_{\mathrm{N}} / \mathrm{Lu}_{\mathrm{N}}=1.47 \pm 0.27$ with the highest values for the Massif Central) and a relative Ce impoverishment (from 0.86 to 0.97 ), which 
Table 2

Mean and standard deviation (SD) REE values for all of the current $(\mathrm{n}=193)$ and herbarium samples $(\mathrm{n}=25)$ and all of the species considered $\left({ }^{*}\right.$ except Tb with 102 current and 12 historical samples, ${ }^{* *}$ sum of REE except Tb). The p-values of the Kruskal-Wallis test between current and historical concentrations are indicated for each REE ( $\mathrm{p}$-values $<0.05$ are in bold).

\begin{tabular}{|c|c|c|c|c|c|}
\hline & \multicolumn{2}{|c|}{$\begin{array}{l}\text { Current samples } \\
(\mathrm{n}=193)\end{array}$} & \multicolumn{2}{|c|}{$\begin{array}{l}\text { Herbarium samples } \\
(\mathrm{n}=25)\end{array}$} & \multirow[t]{2}{*}{$\begin{array}{l}\text { p-value } \\
\text { (Kruskal-Wallis) }\end{array}$} \\
\hline & $\begin{array}{l}\text { Mean } \\
\left(\mu g \cdot g^{-1}\right)\end{array}$ & SD & $\begin{array}{l}\text { Mean } \\
\left(\mu g \cdot g^{-1}\right)\end{array}$ & SD & \\
\hline $\mathrm{La}$ & 0.774 & 0.602 & 3.335 & 6.775 & 0.199 \\
\hline $\mathrm{Ce}$ & 1.470 & 1.210 & 7.505 & 16.300 & 0.105 \\
\hline $\mathrm{Pr}$ & 0.167 & 0.139 & 0.754 & 1.498 & 0.081 \\
\hline $\mathrm{Nd}$ & 0.647 & 0.535 & 2.875 & 5.601 & 0.056 \\
\hline $\mathrm{Sm}$ & 0.124 & 0.102 & 0.538 & 1.037 & 0.064 \\
\hline $\mathrm{Eu}$ & 0.027 & 0.019 & 0.096 & 0.170 & 0.171 \\
\hline $\mathrm{Gd}$ & 0.117 & 0.096 & 0.532 & 1.039 & 0.069 \\
\hline $\mathrm{Tb}^{*}$ & 0.019 & 0.013 & 0.131 & 0.200 & 0.009 \\
\hline Dy & 0.082 & 0.066 & 0.349 & 0.674 & 0.094 \\
\hline Ho & 0.015 & 0.012 & 0.061 & 0.115 & 0.087 \\
\hline $\mathrm{Er}$ & 0.044 & 0.035 & 0.172 & 0.313 & 0.085 \\
\hline $\mathrm{Tm}$ & 0.006 & 0.005 & 0.023 & 0.041 & 0.046 \\
\hline $\mathrm{Yb}$ & 0.040 & 0.032 & 0.148 & 0.255 & 0.103 \\
\hline $\mathrm{Lu}$ & 0.006 & 0.005 & 0.021 & 0.035 & 0.049 \\
\hline LREE** & 3.689 & 2.882 & 15.994 & 33.939 & \\
\hline
\end{tabular}

was also observed by Spickova et al. (2010). Nonetheless, the sum of REE ( $\Sigma$ REE) showed high standard deviations and the highest values for the Midi-Pyrénées region. The REE regional anomalies, as shown in Table 3, were (i) a relative Gd enrichment in LAC and HAU, (ii) positive Eu anomaly in the Massif Central, Vosges and Ardennes, (iii) negative Eu anomaly in the Armorican Massif (with the exception of CHS 35), (iv) Er enrichment in the Vosges and Ardennes and (v) Tm enrichment in the Armorican Massif and Massif Central. The Alps region did not show any pronounced anomalies. Although various lichen and moss species have been considered, the well-correlated REE profiles reflected a regional scale effect within the five main groups: Midi-Pyrénées, Massif Central, Alps, Vosges/Ardennes and Armorican Massif. Indeed, the Massif Central and northeastern regions (Vosges and Ardennes) showed high similarities in the patterns, particularly concerning the LREE and MREE.

\subsubsection{REE patterns in various species}

The lichen and moss REE patterns of 5-6 current sample species and herbarium specimens ( with *) from the four stations BEX (a, Alps), SDV (b, Vosges), BAH (c, Armorican Massif) and PLM (d, Armorican Massif) were plotted in Fig. 5. The REE profiles of the different species were quite similar and consistent with the distribution patterns previously observed for the corresponding regions (Fig. 4) and with the same order of magnitude among the thallus forms: fruticose lichens $<$ foliose lichens $<$ mosses. This is particularly true for the Eu and Er relative enrichment in SDV (Fig. 5b) and for the Tm enrichment in BAH (Fig. 5c). Nevertheless, some differences occurred among the species in the intensities of the positive and negative anomalies, which did not allow for the identification of a generalized trend. For example, the Tm relative enrichment in E. prunastri was more pronounced in PLM than in BAH. Similarly, lichens had a more accentuated Eu anomaly than the mosses (Fig. $5 \mathrm{~b}$ and c). The Eu anomaly in X. parietina and E. prunastri has been related to the anomaly in P. sulcata (eight sites each, Fig. 6); the results indicated a similarly positive pattern, and two specific slopes of 0.61 and 0.83 , respectively could be distinguished.

\subsubsection{REE patterns in herbarium samples}

The REE patterns from the herbarium samples fit remarkably well with the current data, which was shown for the seven considered specimens (Fig. 5a-c). As previously observed for concentrations, the patterns indicated a deviation of REE levels between the historical and current samples. This was consistent with the first results found in the region to the south of the Massif Central (Agnan et al., 2013). Indeed, the general trends and regional anomalies ( $\mathrm{Eu}, \mathrm{Er}$ and $\mathrm{Tm}$ ) were consistent with the historical specimens despite some differences: the $\mathrm{Eu}$ and $\mathrm{Ce}$ anomalies were generally more and less positive, respectively.

\subsection{REE patterns in lichens compared with referential materials}

\subsubsection{Tree bark patterns}

The influence of the tree bark substrate on the lichen REE signature was evaluated by comparing the PAAS-normalized REE distribution patterns of one selected cosmopolitan lichen species (X. parietina) and its most frequent tree bark substrate ( $F$. excelsior) at the three sites ALB, EPC 63 and PSC (Fig. 7a). The bark REE patterns exhibited a higher range (from 0.001 to 0.2 ) compared with those of the lichens (from 0.004 to 0.03 ). No obvious similarity in pattern was observed between the lichen and its corresponding bark for a given site. The regional pattern behaviors and specific anomalies observed in the lichens and lithology were not observed in the bark (except for Tm enrichment in EPC 63 and Ce and Ho impoverishments in PSC). The main example was provided by the Eu anomaly, which was positive in the bark regardless of the considered station. Similarly, the Gd relative enrichment observed in the lichen pattern in ALB was absent in the F. excelsior bark. However, the anomalies observed in EPC 63 could potentially be explained by Ba oxide interference; the high content of Ba could have been involved in the artificial Eu and Sm anomalies, as previously mentioned by Stille et al. (2009).

\subsubsection{Lithology patterns}

The REE distribution patterns of foliose lichen samples were compared with the REE profiles of local lithological substratum (Fig. 7bd). We considered two basalt samples from the Massif Central (Chauvel and Jahn, 1984; Steinmann and Stille, 2008) in EPC 63 (a), two river sediment samples from the Vosges region (Albarède and Semhi, 1995) in SDV and HET 54a (b) and two leucogranite samples (Bernard-Griffiths et al., 1985) in QUI and PLM (c).

The REE distribution patterns of the considered substratum found in the literature above were of the same order of magnitude as the PAAS (ratio of approximately 1 ). The REE substratum patterns correlated well with the general REE lichen/moss patterns. Moreover, a converging positive Eu anomaly can be found in the Massif Central and Vosges (although the Vosges substratum was not a bedrock but rather a bed load sediment, i.e., a product of bedrock erosion composed of quartz and feldspar (Albarède and Semhi, 1995)), negative Eu anomaly can be found in the Armorican Massif (although the lichen distribution patterns were more flattened) and Tm enrichment and a high $\mathrm{La}_{N} / \mathrm{Lu}_{N}$ 


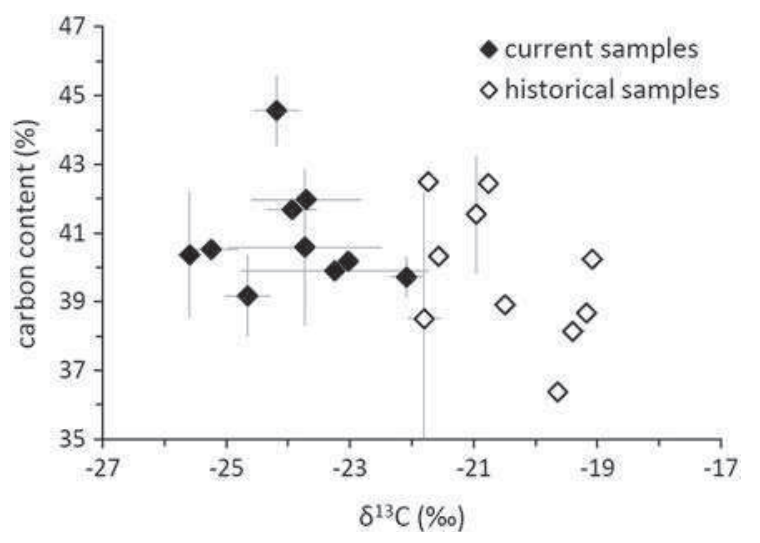

Fig. 2. The total carbon content vs $\delta^{13} \mathrm{C}$ of 10 current (in black) and 10 herbarium (in white) lichen samples. Each data point corresponds to the mean of the two samples.

ratio ( 1.74 and 2.04 on average for basalts and lichens, respectively) can be found in the Massif Central.

\section{Discussion}

\subsection{Influence of lichen or moss species on REE pattern}

In environmental studies, the influence of biological material on trace metal bioaccumulation remains a matter of discussion (Szczepaniak and Biziuk, 2003; Bergamaschi et al., 2007; Basile et al., 2008). The investigation of REE bioaccumulation by lichens has generally considered only one or two species (Spickova et al., 2010; Aubert et al., 2002). However, the influence of species on REE content was shown for higher plants (Tyler, 2004; Ding et al., 2005; Miao et al., 2008). In this study, we considered several lichen and moss species to evaluate their influence on REE patterns. Our results showed that although the concentration levels depend on the considered group differentiated mainly by morphological criteria (foliose lichens, fruticose lichens and mosses), the species criteria contributed only slightly to the specificity of the REE pattern profiles (Fig. 5). A PCA was plotted using standard $\Sigma$ REE normalized data from all of the stations distinguishing foliose lichens $(n=131)$, fruticose lichens $(\mathrm{n}=48)$ and mosses $(\mathrm{n}=14)$ (Fig. 8a-b). Mosses were located in between the foliose and fruticose lichens on the second axis $(20 \%$ of the data variance) driven by La on the positive side and by $\mathrm{Nd}$ and $\mathrm{Pr}$ on the negative side. The Kruskal-Wallis test $(\alpha=0.05)$ produced a significant difference but only for the minor component (axis 2) between foliose and fruticose lichens $(p=0)$ and foliose lichens and mosses $(\mathrm{p}=0.023)$. This meant that the considered group had a limited influence on REE accumulations, despite the different levels of concentration (normalized by the $\Sigma$ REE). This was also illustrated by the Eu anomaly in Fig. 6, which had a higher intensity for E. prunastri than for $X$. parietina compared with $P$. sulcata. This most likely resulted from the morphological effect of the lichen; in fruticose lichens, the threedimensional structure involved a higher biomass for a given volume to trap atmospheric particles (Nieboer et al., 1978) and implied a dilution effect compared with foliose lichens.

Consequently, the REE signal is essentially the same regardless of the considered species. However, we recommend that the same species, or at least species that have the same morphologies, should be sampled to ensure an accurate comparison between sites when possible. For all cases, the species criterion must be mentioned in biomonitoring studies.

\subsection{Influence of tree bark on REE patterns in lichens}

The REE distribution pattern found in the F. excelsior bark (Fig. 7a) showed a complex behavior. Although the mechanisms governing the compartmentalization of REE in plants are not completely known, the metabolic processes appear to play a significant role in the fractionation of these elements in the different compartments; for example, roots are more REE-enriched than wood and leaves (Stille et al., 2006). The few similarities observed between the lichen and bark distribution patterns (Tm enrichment in EPC 63 and Ho impoverishment in SGP) implied either a common source (atmospheric or a potential transfer from one compartment to another), a similar geochemical behavior (e.g., substitution or redox processes), or a mixture of sources and behaviors. However, the positive Eu anomaly found in the bark regardless of the station, even in areas characterized by depleted Eu lithology (Armorican Massif, Fig. 7d), supports a distinct origin of REE among bark and lichens. This anomalous consistency could be explained by a biological action because it has previously been found that lower $\Sigma$ REE in wood and bark corresponds with higher anomalies (Stille et al., 2006). A substitution of $\mathrm{Ca}^{2+}$ for $\mathrm{Eu}^{3+}$ in bark (Zeng et al., 2003) may be hypothesized. Indeed, calcium is known to be stored in plant tissues as an inactive form, such as oxalate crystal (Franceschi and Horner, 1980), and plays an important physiological role in the cambium layer (Fromm, 2010).

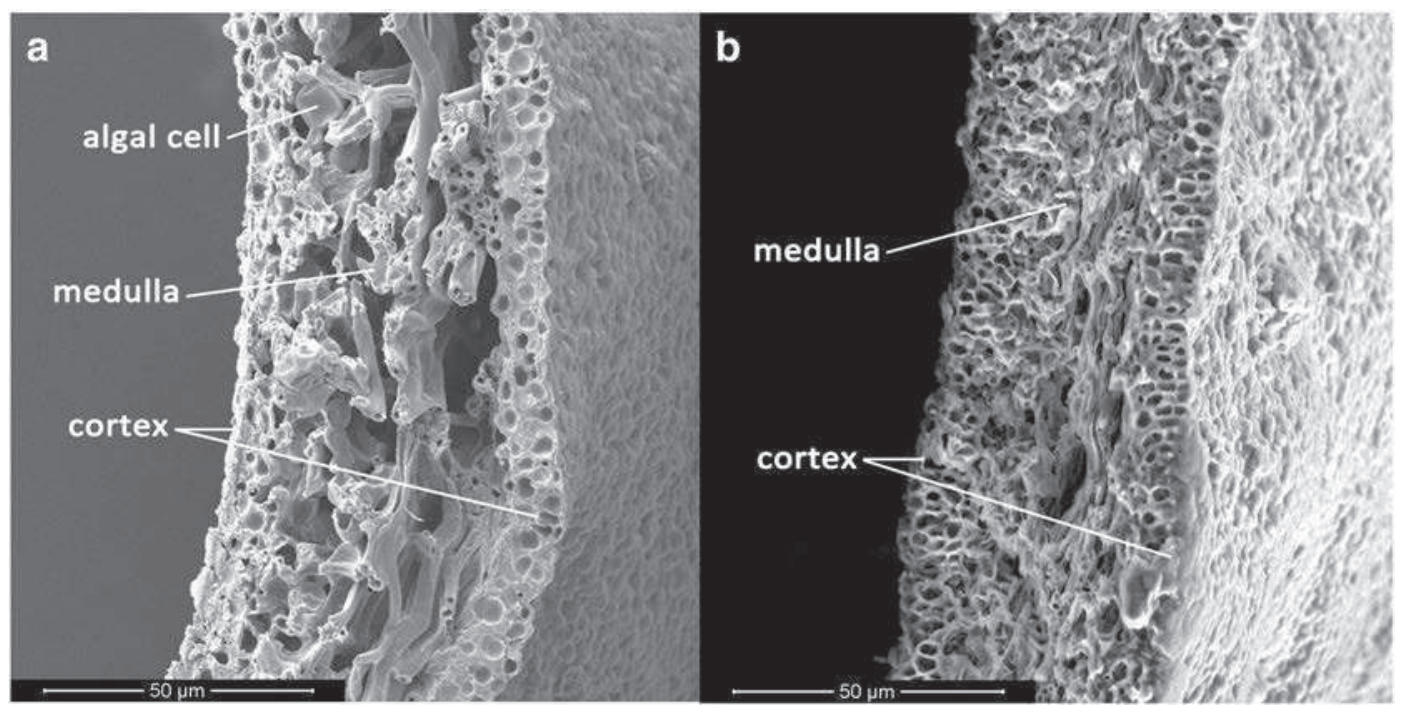

Fig. 3. SEM observations of current (a) and historical (b) X. parietina samples with $2.65 \cdot 10^{-3} \mathrm{~Pa} / 5 \mathrm{kV}$ and $161 \mathrm{~Pa} / 10 \mathrm{kV}$ characteristics, respectively. 
a

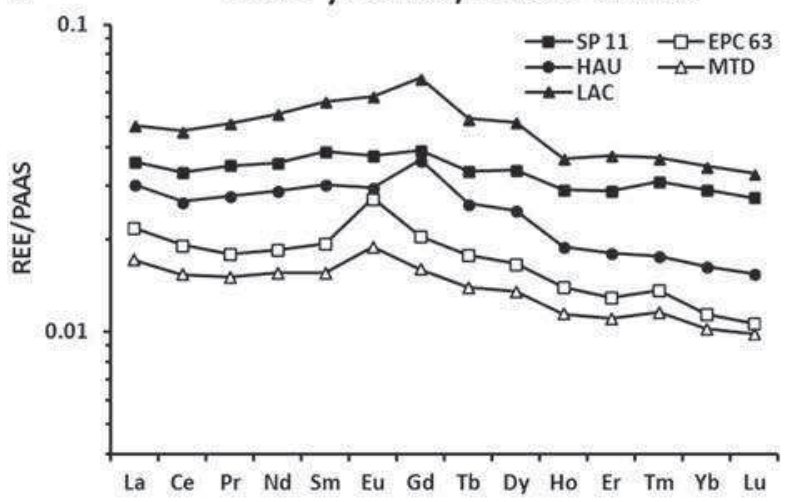

C

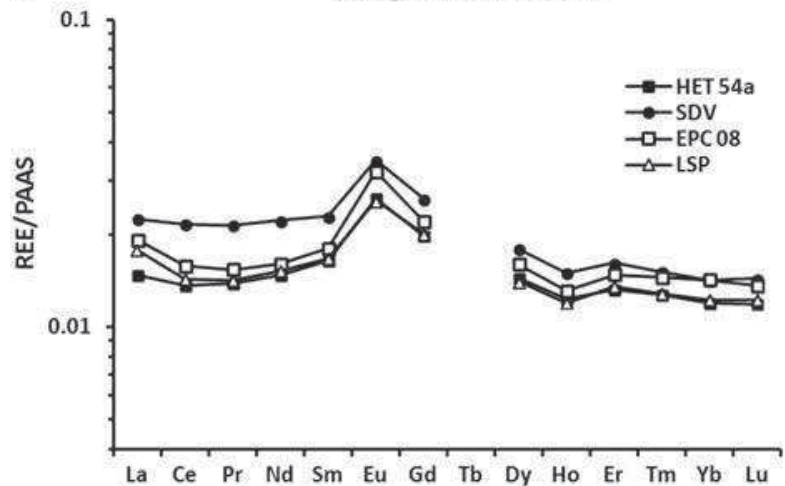

b

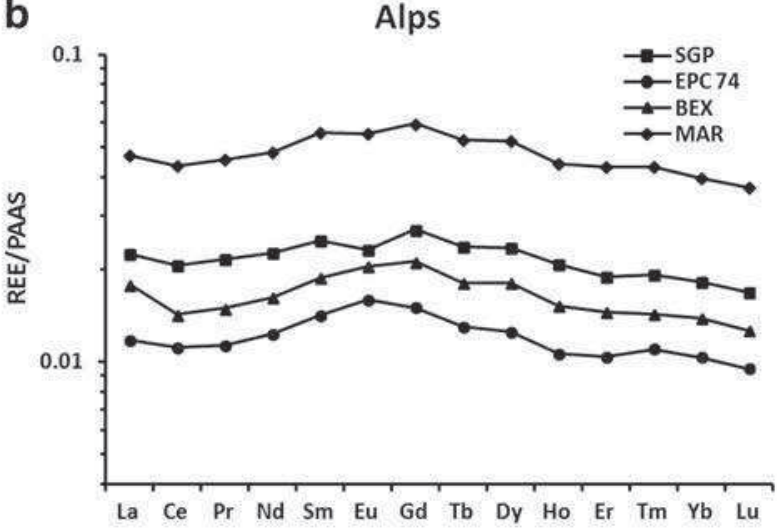

d

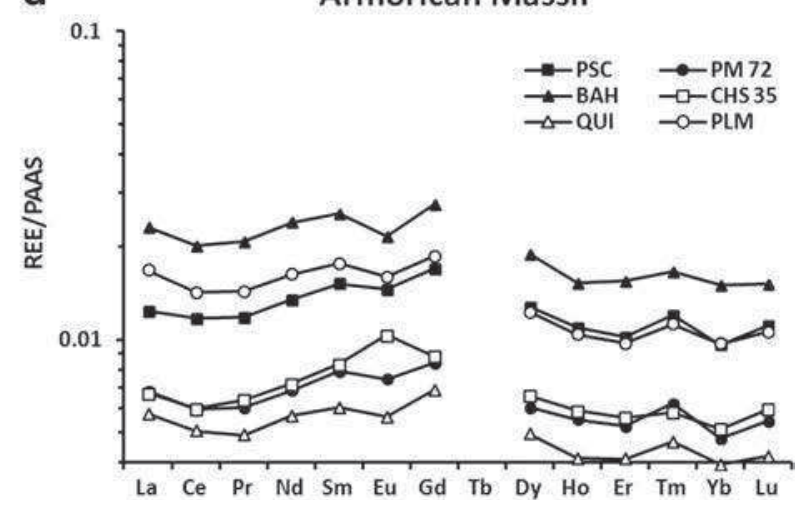

Fig. 4. PAAS-normalized REE profiles of lichens and mosses from 19 stations distinguishing the 6 studied regions (see Fig. 1 for locations). Terbium was not analyzed for the Vosges, Ardennes and Armorican Massif (absent from the ICP-MS internal standard). Note the y-axis logarithm scale.

This Eu signature in bark, which is most likely related to biological activities that are not found in lichens, suggests an absence of trace element transfer from the bark to the lichen. Consequently, lichens were more robust in registering atmospheric particles originating from bedrock and/or soil erosion at the regional scale than bark that is sometimes used for trace metal monitoring (Catinon et al., 2009).

\subsection{Past and present origin of REE in lichens and mosses}

The intra-station variability was lower than the variability between the different regions (Fig. 4). The regional influence dominated the REE distribution patterns and prevailed over the station scale effect (e.g., Eu in CHS 35 in the Armorican Massif). The analogy between lichen

Table 3

REE characteristic values of current samples for all of the stations showing the Eu, Gd, Er, and Tm anomalies, La/Lu and sum of the REE without Tb ( $\Sigma$ REE). All of the species are considered. The values in bold indicate the anomaly values $>1.2$ or $\mathrm{La}_{N} / \mathrm{Lu}_{\mathrm{N}}>1.5$. The asterisks represent the expected values.

\begin{tabular}{|c|c|c|c|c|c|c|c|c|c|c|c|c|c|c|c|}
\hline \multirow[b]{2}{*}{ Region } & \multirow[b]{2}{*}{ Station } & \multicolumn{2}{|c|}{$\mathrm{Ce}_{\mathrm{N}} / \mathrm{Ce}_{\mathrm{N}}{ }^{*}$} & \multicolumn{2}{|c|}{$\mathrm{Eu}_{\mathrm{N}} / \mathrm{Eu}_{\mathrm{N}}{ }^{*}$} & \multicolumn{2}{|c|}{$\mathrm{Gd}_{\mathrm{N}} / \mathrm{Gd}_{\mathrm{N}}{ }^{*}$} & \multicolumn{2}{|c|}{$\mathrm{Er}_{\mathrm{N}} / \mathrm{Er}_{\mathrm{N}}{ }^{*}$} & \multicolumn{2}{|c|}{$\mathrm{Tm}_{\mathrm{N}} / \mathrm{Tm}_{\mathrm{N}}{ }^{*}$} & \multicolumn{2}{|c|}{$\mathrm{La}_{\mathrm{N}} / \mathrm{Lu}_{\mathrm{N}}$} & \multicolumn{2}{|l|}{$\sum$ REE } \\
\hline & & Mean & SD & Mean & SD & Mean & SD & Mean & SD & Mean & SD & Mean & SD & Mean & SD \\
\hline \multirow[t]{5}{*}{ Midi-Pyrénées } & SP 11 & 0.94 & 0.01 & 0.94 & 0.07 & 1.11 & 0.03 & 0.98 & 0.08 & 1.05 & 0.07 & 1.32 & 0.12 & 6.25 & 2.84 \\
\hline & TOU & 0.95 & 0.01 & 0.92 & 0.03 & 1.25 & 0.05 & 1.01 & 0.02 & 1.03 & 0.06 & 1.54 & 0.15 & 8.02 & 5.20 \\
\hline & ALB & 0.97 & 0.04 & 1.03 & 0.10 & 1.19 & 0.08 & 1.01 & 0.09 & 1.05 & 0.21 & 1.45 & 0.22 & 4.48 & 2.04 \\
\hline & HAU & 0.91 & 0.08 & 0.94 & 0.25 & 1.29 & 0.20 & 0.98 & 0.06 & 1.02 & 0.06 & 2.01 & 0.66 & 5.05 & 1.86 \\
\hline & LAC & 0.95 & 0.00 & 0.99 & 0.08 & 1.21 & 0.06 & 1.02 & 0.02 & 1.03 & 0.04 & 1.38 & 0.10 & 7.90 & 2.33 \\
\hline \multirow{2}{*}{ Massif Central } & ЕРС 63 & 0.95 & 0.06 & 1.41 & 0.19 & 0.90 & 0.08 & 0.93 & 0.07 & 1.14 & 0.13 & 2.15 & 0.67 & 3.45 & 0.67 \\
\hline & MTD & 0.95 & 0.03 & 1.18 & 0.15 & 0.97 & 0.07 & 0.94 & 0.12 & 1.16 & 0.27 & 1.80 & 0.50 & 2.95 & 2.15 \\
\hline \multirow[t]{4}{*}{ Alps } & SGP & 0.93 & 0.02 & 0.91 & 0.07 & 1.13 & 0.04 & 0.95 & 0.13 & 1.02 & 0.16 & 1.31 & 0.30 & 3.95 & 2.24 \\
\hline & EPC 74 & 0.95 & 0.04 & 1.13 & 0.19 & 1.02 & 0.14 & 0.97 & 0.14 & 1.09 & 0.24 & 1.27 & 0.27 & 2.24 & 1.36 \\
\hline & BEX & 0.86 & 0.02 & 1.05 & 0.11 & 1.08 & 0.08 & 0.98 & 0.08 & 1.03 & 0.16 & 1.50 & 0.30 & 2.74 & 1.01 \\
\hline & MAR & 0.94 & 0.02 & 0.97 & 0.04 & 1.10 & 0.02 & 0.99 & 0.03 & 1.04 & 0.05 & 1.27 & 0.14 & 8.39 & 2.79 \\
\hline \multirow[t]{2}{*}{ Vosges } & HET 54a & 0.94 & 0.02 & 1.59 & 0.65 & & & 1.06 & 0.04 & 1.01 & 0.04 & 1.27 & 0.14 & 1.99 & 1.31 \\
\hline & SDV & 0.94 & 0.06 & 2.10 & 1.04 & & & 1.07 & 0.08 & 1.01 & 0.10 & 1.46 & 0.22 & 2.83 & 2.72 \\
\hline \multirow{2}{*}{ Ardennes } & EPC 08 & 0.90 & 0.03 & 1.62 & 0.56 & & & 1.07 & 0.06 & 0.99 & 0.05 & 1.48 & 0.19 & 2.03 & 1.03 \\
\hline & LSP & 0.86 & 0.08 & 1.60 & 0.39 & & & 1.09 & 0.06 & 1.00 & 0.07 & 1.55 & 0.27 & 2.25 & 1.68 \\
\hline \multirow[t]{6}{*}{ Armorican Massif } & PSC & 0.97 & 0.01 & 0.88 & 0.08 & & & 0.90 & 0.10 & 1.21 & 0.12 & 1.16 & 0.23 & 2.16 & 1.19 \\
\hline & PM 72 & 0.93 & 0.01 & 0.91 & 0.07 & & & 0.93 & 0.18 & 1.22 & 0.37 & 1.34 & 0.32 & 1.17 & 0.17 \\
\hline & $\mathrm{BAH}$ & 0.89 & 0.05 & 0.85 & 0.11 & & & 0.98 & 0.07 & 1.09 & 0.10 & 1.60 & 0.33 & 4.21 & 3.56 \\
\hline & CHS 35 & 0.91 & 0.02 & 1.30 & 0.25 & & & 0.93 & 0.10 & 1.13 & 0.16 & 1.10 & 0.25 & 1.19 & 0.61 \\
\hline & QUI & 0.95 & 0.03 & 0.83 & 0.12 & & & 0.95 & 0.04 & 1.14 & 0.09 & 1.54 & 0.40 & 0.95 & 0.40 \\
\hline & PLM & 0.91 & 0.03 & 0.88 & 0.07 & & & 0.90 & 0.07 & 1.16 & 0.15 & 1.65 & 0.29 & 3.43 & 2.68 \\
\hline
\end{tabular}


a

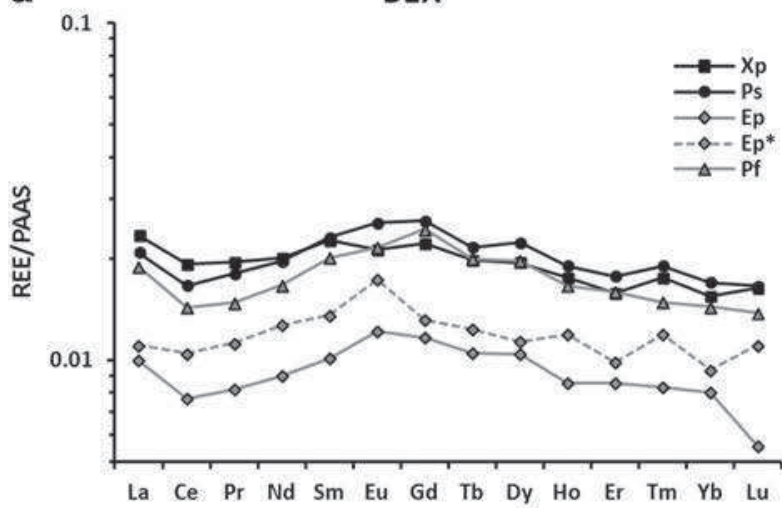

b SDV

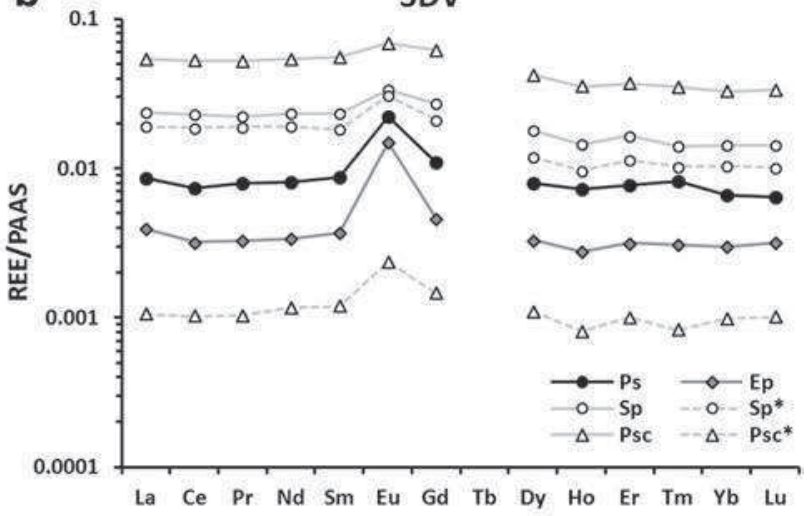

d

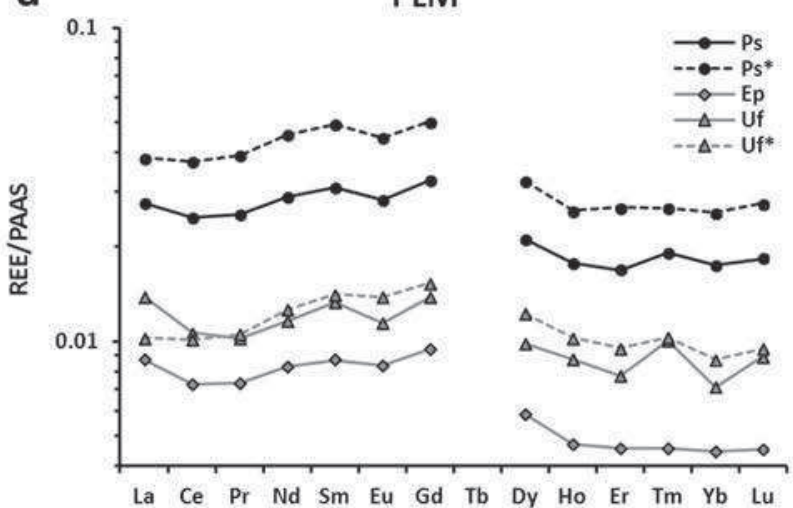

Fig. 5. PAAS-normalized REE profiles in lichens and mosses at BEX (a), Saint-Dié-des-Vosges (b), Bazoches-au-Houlme (c) and Plounéour-Ménez (d), with the current species distinguished by a solid line and herbarium samples* by a dotted line. Foliose lichens are in black, fruticose lichens are in dark gray and mosses are in light gray. Terbium was not analyzed for the Vosges and Armorican Massif (absent from the ICP-MS internal standard). Note the y-axis logarithm scale.

and local bedrock profiles (Fig. 7) suggests an influence of the regional lithology on the lichen REE content and confirms the observations of Rusu et al. (2006). The dry particles derived from bedrock chemical and physical erosion (Sugimae, 1980) could be trapped by lichens during atmospheric deposition processes, e.g., wind and rain phenomena. The REE from particles with oxi-hydroxide affinity (Sholkovitz, 1995) could thus be accumulated similar to other metal elements (Gandois et al., 2010a). The positive Eu anomaly registered in lichens growing in basaltic regions (Massif Central with 1.30) and negative Eu anomaly in granitic environments ( 0.94 for HAU or 0.83 for QUI) obviously

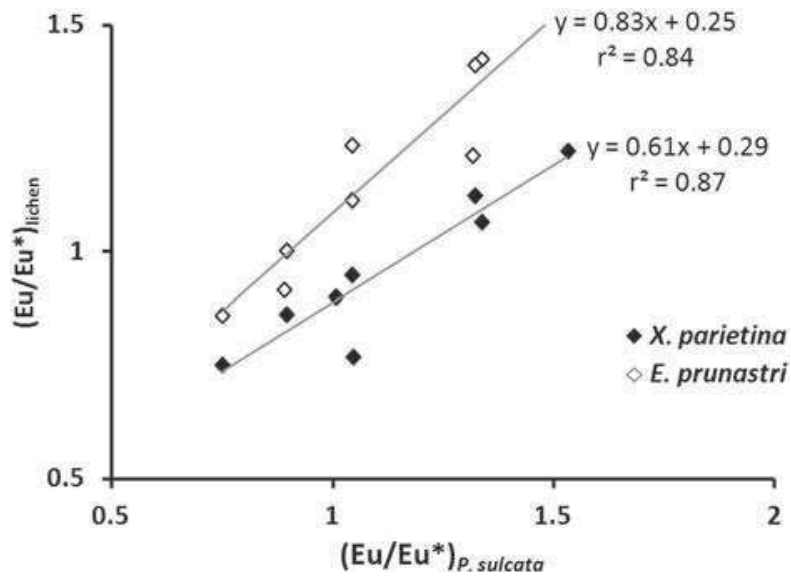

Fig. 6. Relationship between the Eu anomaly in X. parietina (in black) or E. prunastri (in white) and in P. sulcata. supports this hypothesis. The $\mathrm{Eu}^{2+}$ ion is a compatible element dissimilar to the other trivalent REE that enables incorporation into minerals, especially of calcic minerals such as plagioclase feldspars by the substitution of $\mathrm{Eu}^{2+}$ for $\mathrm{Ca}^{2+}$ (Weill and Drake, 1973). Thus, it is possible to observe positive Eu anomalies in basalts and negative anomalies in granitoids (Gromet and Silver, 1983), with mica groups characterized by Eu depletion (Aubert et al., 2001). Two PCA were plotted, and they considered the foliose lichens growing in magmatic rock regions (Fig. $8 \mathrm{c}, \mathrm{n}=45$ ) and those growing in sedimentary rock regions (Fig. 8d, $\mathrm{n}=86$ ). In each case, the samples were grouped together depending on the rock: basalt, granite and schist for magmatic substrates (Fig. 8c) and limestone, sandstone and alluvium for sedimentary substrates (Fig. 8d). Only REE in lichens from granite and schist regions (axis 1), sandstone and alluvium (axis 1) and limestone and alluvium (axis 2 ) were not significantly different ( $p>0.05$, Kruskal-Wallis test, $\alpha=0.05$ ). The most important difference in REE accumulated in lichens was between granite and basalt. The magmatic substrates could better discriminate one station from another because of two principal reasons. First, the magmatic bedrocks belonged to the same formations (e.g., basalt from Quaternary volcanism in the Massif Central, Hercynian granite in Armorican Massif), which led to a strong REE signature homogeneity; this result was in contrast to the sedimentary substrates, which comprised many different rock types (limestone, sandstone, chalk, alluvium, clay, moraine and molasse). Second, the magmatic rocks containing higher REE than sedimentary substrates facilitated the diffusion of their geochemical signatures (Condie, 1993; Plank and Langmuir, 1998). Although magmatic substrates were more resistant to weathering processes than sedimentary substrates, the minerals providing the geochemical signature (biotite and feldspar in granites and basalts, respectively) were more susceptible to weathering in the 
a

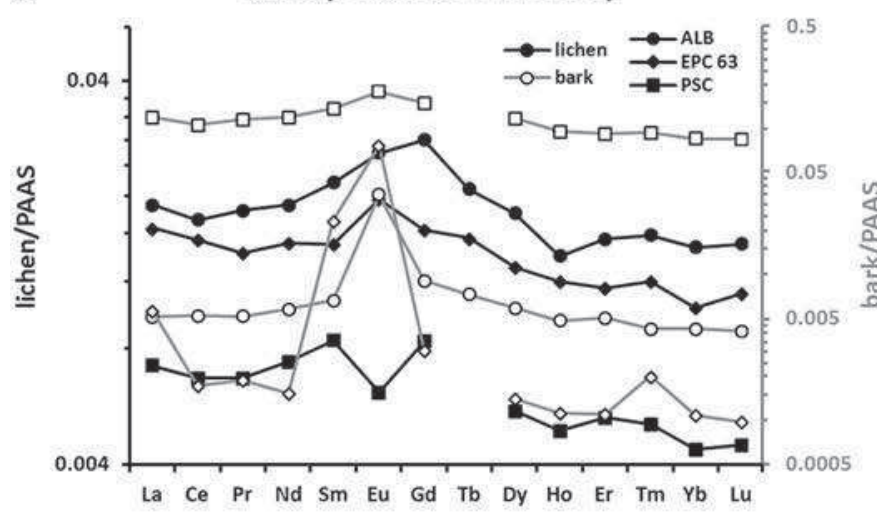

C

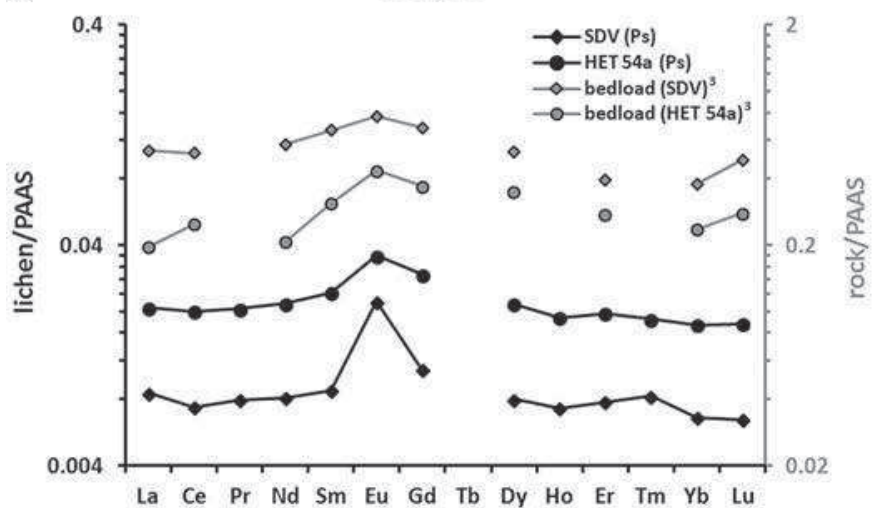

b

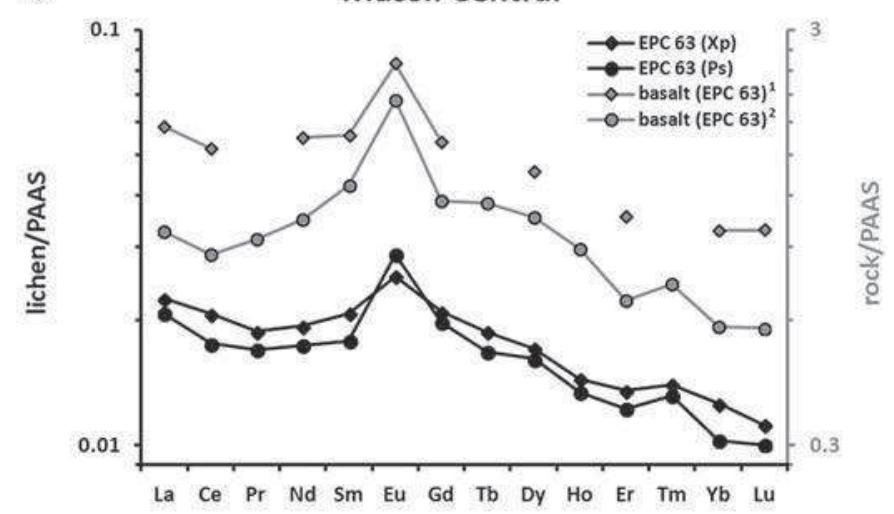

d

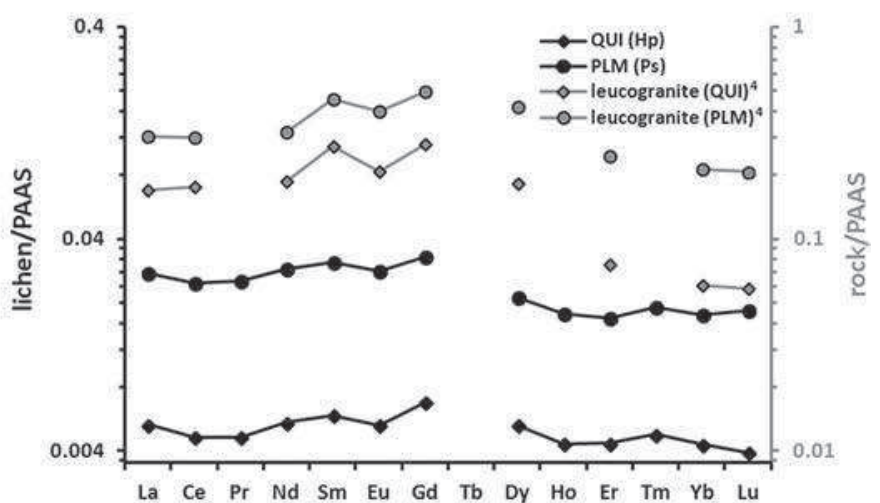

Fig. 7. Comparison between PAAS-normalized REE profiles in lichens and reference materials: local substratum for Massif Central (a), Vosges (b) and Armorican Massif (c) $\left({ }^{1}\right.$ Chauvel and Jahn, 1984; ${ }^{2}$ Steinmann and Stille, 2008; ${ }^{3}$ Albarède and Semhi, $1995 ;{ }^{4}$ Condie, $1993 ;{ }^{5}$ Bernard-Griffiths et al., 1985), and F. excelsior bark supporting X. parietina from four sites (d). Lichens are in black on the left (first y-axis) and the reference material is in gray on the right (second y-axis).

Bowen's reaction series (Bowen, 1922). This could also explain the influence of the crystalline massifs to their geographical limits; for example, the PSC near the Armorican Massif. In contrast, the Vosges and Ardennes stations were both under the local geological influence of the same origin (Early Triassic).

The robustness of the interpretation of such a natural geochemical signature was confirmed by the herbarium data. Only a natural pressure could explain this consistency over one century. Thus, the Gd relative enrichment in the Midi-Pyrénées region, as previously observed in both the 1900 and 2010 samples (Agnan et al., 2013) and the soil layers and sedimentary bedrock from the same region (Redon et al., in progress), could be explained by crustal influence rather than by anthropogenic contamination, which was dissimilar to the aquatic systems that could be observed as a result of hospital activities (Bau and Dulski, 1996; Kümmerer and Helmers, 2000; Knappe et al., 2005; Rabiet et al., 2009). The only noticeable change between the historical and current samples was the REE content (Table 2 and Supplementary data), which was obviously higher in the past. Apart from a hypothetic larger historical dust deposition in the past, this difference could also be explained by a possible biological damage to the herbarium samples, such as organic degradation as a result of microbial activity that led to a concentration of mineral elements (such as trace metals) for an equivalent weight. Indeed, the hypothesis of organic matter degradation was sustained by the less negative $\delta^{13} \mathrm{C}$ in the historical samples (Fig. 2) (Natelhoffer and Fry, 1988; Boström et al., 2007). The SEM observations (Fig. 3) also supported this degradation. This confirmed that the conservation state of organic tissues could influence the relative inorganic content.

Consequently, comparing the concentrations between past and present was not adequate. It was worthwhile to use normalized data such as the PAAS-normalization for REE to investigate and compare the REE signatures. Considering these recommendations, the herbarium samples were valuable tools to assess the characteristics of atmospheric deposition in the past, namely when data were missing.

The REE in atmospheric bulk deposition were mainly found in particles (Heaton et al., 1990), which is explained by their affinity for oxide elements (Koeppenkastrop et al., 1991). Thus, aerosols derived from local bedrock and/or soil weathering produced the regional lithologic REE signatures in the lichen content, which was supported by our observations (Figs. 7b-d and 8c-d). Although we cannot locate the recorded lithologic dust because of the use of total mineralization (thallus surface deposition or incorporation into the thallus), the converging temporal signatures confirmed the robustness of lichens and mosses in integrating atmospheric dust at the regional scale. At the national scale, the data supported REE bioaccumulation in lichens and mosses in remote areas from atmospheric deposition with little or no influence from anthropogenic inputs, which was illustrated by an absence of LREE enrichment that characterized the urban aerosols (Zhang and Liu, 2004). Moreover, the influence of tree species, bark substrate or throughfall chemical composition (Aubert et al., 2002; Spickova et al., 2010) was not found. The non-significant difference between the two coastal stations (QUI and PLM in the Armorican Massif) and other Armorican stations excluded the influence of sea-spray. Indeed, the seawater REE patterns were characterized by a high negative $\mathrm{Ce}$, and an Eu anomaly; LREE enrichment was not observed in these sites (Elderfield and Greaves, 1982). This was related to the low REE content in seawater compared with mineral REE concentrations. Moreover, the relative depletion observed for HREE ( $\mathrm{La} / \mathrm{Lu}>1$ ) in all of the stations could be related to the crustal signature, in which the fractionation between LREE and HREE depended on the particle sizes (Spickova et al., 2010; Suzuki et al., 2011). Consequently, we proposed that these generalized patterns 
a
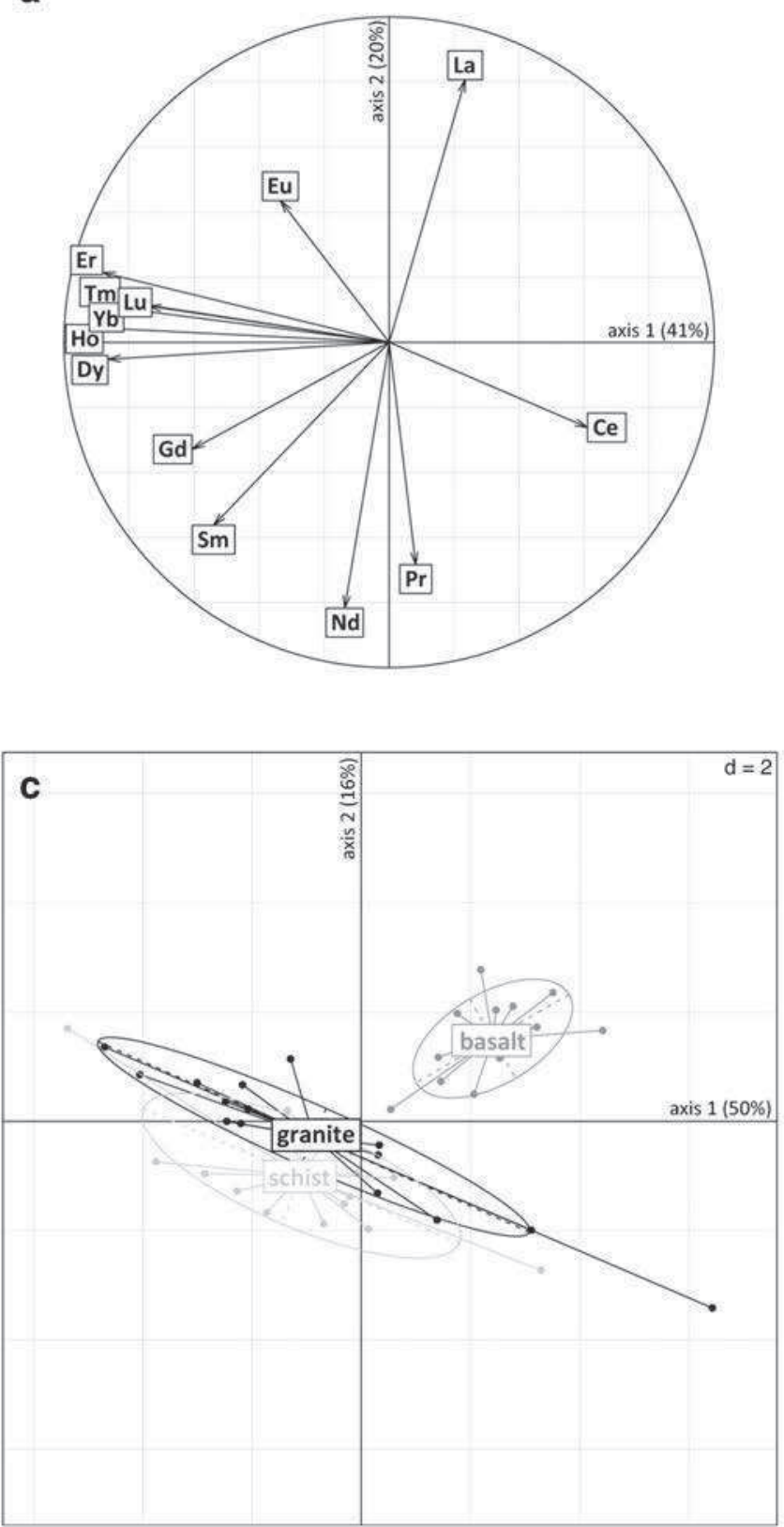
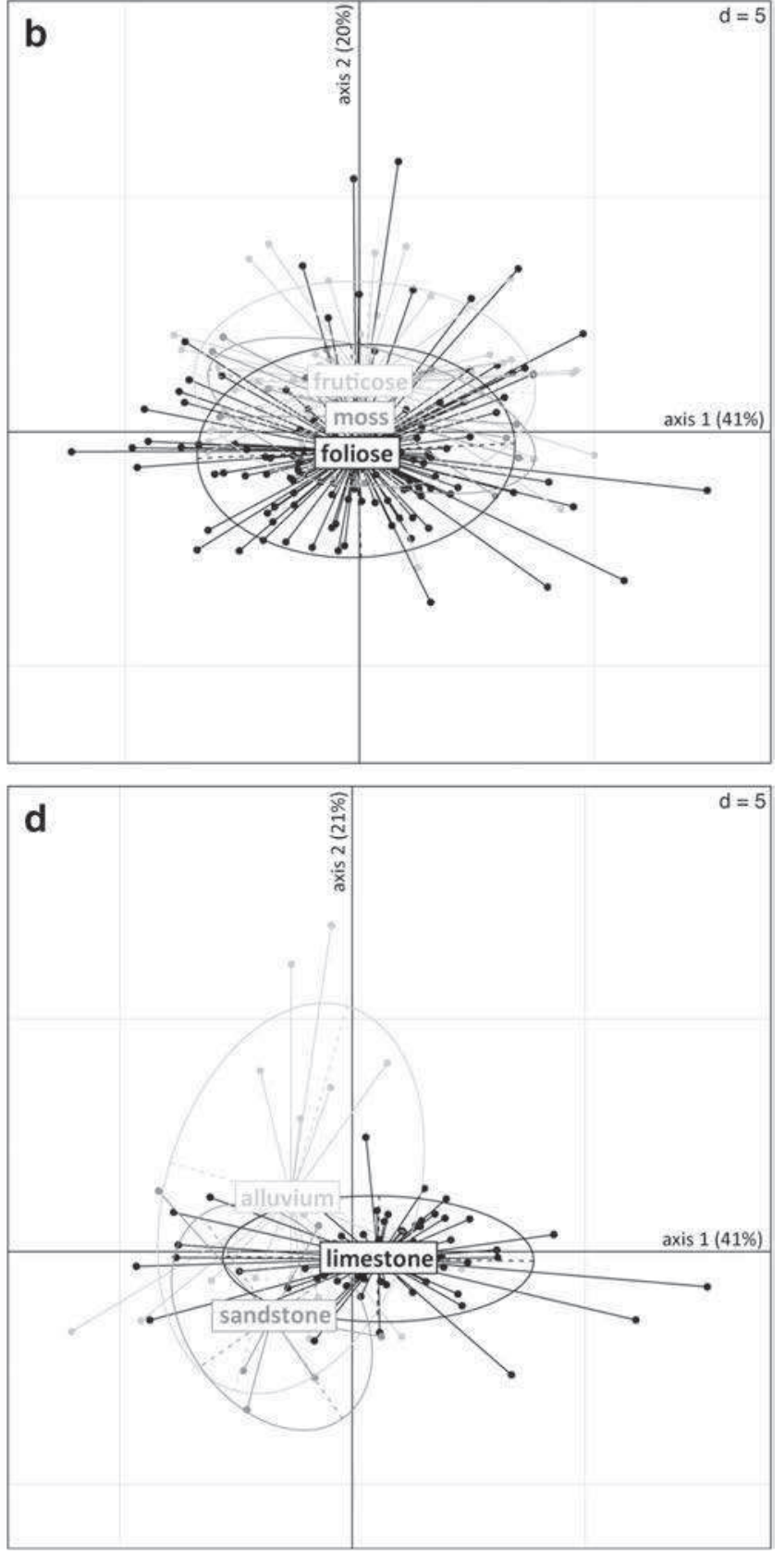

Fig. 8. Principal component analysis on standard $\Sigma$ REE-normalized data for 193 current samples of lichens and mosses by variable (a) or observation (b), 45 current foliose lichens developed in magmatic substratum regions (c), and 86 current foliose lichens developed in sedimentary substratum regions (d).

observed in lichens and mosses reflected a crustal signature prevailing at the regional scale and were not a result of the preferential assimilation of HREE (Chiarenzelli et al., 2001) or leaching of LREE from atmospheric particles (Aubert et al., 2006), as hypothesized by these authors. Moreover, the use of biomonitors allowed the seasonal variation measured in atmospheric deposition to be limited (Spickova et al., 2010; Suzuki et al., 2011).

Through the REE investigations, we showed that the (i) registered lithologic particle deposition was preserved in lichens and mosses from the herbarium samples and (ii) in each region, the lithological signature of the registered particles had not changed over time.

\section{Conclusions}

This REE study in various regions of France away from sources of contamination aimed to investigate atmospheric deposition using a variety of lichen and moss species as bioaccumulators. The registered geochemical signatures (such as the general trend of REE distribution patterns and Eu or Tm anomalies) after total digestion indicated a regional lithological source of dust particles derived from bedrock and/or soil weathering entrapped by lichens and mosses that erased any anthropogenic influence. This implies that in remote areas, the particles recorded in lichens and mosses were influenced mainly at the regional scale. The use of herbarium specimens collected since 1870 confirmed this observation in each of the corresponding sites. Moreover, the species influence (between mosses and lichens or between foliose lichens and fruticose lichens) appeared to be minor against these regional influences, which were between foliose lichens. Nevertheless, for comparison purposes, it was recommended to consider the same species or same thallus morphology whenever possible and use normalized REE data to erase the concentration effect that occurs because of organic matter degradation in historical samples. Indeed, 
both lichens and mosses are robust organisms for indicating presentday or past lithologic dust deposition because an influence of bark on REE accumulation was not detected in the lichen samples.

Supplementary data to this article can be found online at http://dx. doi.org/10.1016/j.scitotenv.2014.03.132.

\section{Acknowledgments}

This project benefited from financial support number 1062C0019 from ADEME (French Agency for Environment). The authors would like to thank Paul Seimandi and Dominique Mazau from the University Toulouse III Herbarium for kindly providing the lichen samples. MarieJosé Tavella, Carole Boucayrand, Manuel Henry and Jonathan Prunier are thanked for their assistance during the cleanroom dissolution procedure, Frédéric Candaudap, Aurélie Lanzanova, David Baqué and Issam Moussa are thanked for their assistance in the ICP analyses and Yves Martinez, Isabelle Fourquaux, Bruno Payré, and Dominique Goudounèche are thanked for their assistance in the SEM observations. We are grateful for the helpful comments provided by three anonymous reviewers, and the improvements made by James P. Bennett. Yannick Agnan was funded with an ADEME fellowship.

\section{References}

Agnan Y, Séjalon-Delmas N, Probst A. Comparing early twentieth century and presentday atmospheric pollution in SW France: a story of lichens. Environ Pollut 2013; 172:139-48.

Albarède F, Semhi K. Patterns of elemental transport in the bedload of the Meurthe River (NE France). Chem Geol 1995;122(1-4):129-45.

Aubert D, Stille P, Probst A. REE fractionation during granite weathering and removal by waters and suspended loads: $\mathrm{Sr}$ and Nd isotopic evidence. Geochim Cosmochim Acta 2001;65(3):387-406.

Aubert D, Stille P, Probst A, Gauthier-Lafaye F, Pourcelot L, Del Nero M. Characterization and migration of atmospheric REE in soils and surface waters. Geochim Cosmochim Acta 2002;66(19):3339-50.

Aubert D, Le Roux G, Krachler M, Cheburkin A, Kober B, Shotyk W, et al. Origin and fluxes of atmospheric REE entering an ombrotrophic peat bog in Black Forest (SW Germany): evidence from snow, lichens and mosses. Geochim Cosmochim Acta 2006;70(11):2815-26.

Azimi S, Ludwig A, Thévenot DR, Colin J-L. Trace metal determination in total atmospheric deposition in rural and urban areas. Sci Total Environ 2003;308(1-3):247-56.

Bargagli R, Nimis PL. Guidelines for the use of epiphytic lichens as biomonitors of atmospheric deposition of trace elements. In: Nimis PL, Scheidegger C, Wolseley PA, editors. Earth and environmental sciences, vol. 7. Dordrecht: Kluwer/NATO Science Series; 2002 p. 295-9.

Basile A, Sorbo S, Aprile G, Conte B, Cobianchi RC. Comparison of the heavy metal bioaccumulation capacity of an epiphytic moss and an epiphytic lichen. Environ Pollut 2008;151(2):401-7.

Bau M, Dulski P. Anthropogenic origin of positive gadolinium anomalies in river waters. Earth Planet Sci Lett 1996:143(1-4):245-55.

Beck A, Mayr C. Nitrogen and carbon isotope variability in the green-algal lichen Xanthoria parietina and their implications on mycobiont-photobiont interactions. Ecol Evol 2012;2(12):3132-44.

Bergamaschi L, Rizzio E, Giaveri G, Loppi S, Gallorini M. Comparison between the accumulation capacity of four lichen species transplanted to a urban site. Environ Pollut 2007;148(2):468-76.

Bernard-Griffiths J, Peucat JJ, Sheppard S, Vidal P. Petrogenesis of Hercynian leucogranites from the southern Armorican Massif: contribution of REE and isotopic ( $\mathrm{Sr}, \mathrm{Nd}, \mathrm{Pb}$ and 0) geochemical data to the study of source rock characteristics and ages. Earth Planet Sci Lett 1985;74(2-3):235-50.

Boström B, Comstedt D, Ekblad A. Isotope fractionation and ${ }^{13} \mathrm{C}$ enrichment in soil profiles during the decomposition of soil organic matter. Oecologia 2007;153:89-98.

Bowen NL. The reaction principle in petrogenesis. J Geol 1922;30(3):177-98.

Cantrell KJ, Byrne RH. Rare earth element complexation by carbonate and oxalate ions. Geochim Cosmochim Acta 1987;51(3):597-605.

Carignan J, Gariepy C. Isotopic composition of epiphytic lichens as a tracer of the sources of atmospheric lead emissions in southern Quebec, Canada. Geochim Cosmochim Acta 1995;59(21):4427-33.

Catinon M, Ayrault S, Clocchiatti R, Boudouma O, Asta J, Tissut M, et al. The anthropogenic atmospheric elements fraction: a new interpretation of elemental deposits on tree barks. Atmos Environ 2009;43(5):1124-30.

Chauvel C, Jahn B. Nd-Sr isotope and REE geochemistry of alkali basalts from the Massif Central, France. Geochim Cosmochim Acta 1984:48:93-110.

Chiarenzelli J, Aspler L, Dunn C, Cousens B, Ozarko D, Powis K. Multi-element and rare earth element composition of lichens, mosses, and vascular plants from the Central Barrenlands, Nunavut, Canada. Appl Geochem 2001;16(2):245-70

Condie KC. Chemical composition and evolution of the upper continental crust: contrasting results from surface samples and shales. Chem Geol 1993;104(1-4):1-37.
Conti ME, Cecchetti G. Biological monitoring: lichens as bioindicators of air pollution assessment - a review. Environ Pollut 2001;114(3):471-92.

De Bruin M, Hackenitz E. Trace element concentrations in epiphytic lichens and bark substrate. Environ Pollut B Chem Phys 1986;11:153-60.

Ding SM, Liang T, Zhang CS, Yan JC, Zhang ZL. Accumulation and fractionation of rare earth elements (REEs) in wheat: controlled by phosphate precipitation, cell wall absorption and solution complexation. J Exp Bot 2005;56(460):2765-75.

Dolegowska S, Migaszewski ZM. Anomalous concentrations of rare earth elements in the moss-soil system from south-central Poland. Environ Pollut 2013;178:33-40.

Elderfield H. Greaves MJ. The rare earth elements in seawater. Nature 1982;296:214-9.

Franceschi VR, Horner HT. Calcium oxalate crystals in plants. Bot Rev 1980;46(4): 361-427

Fromm J. Wood formation of trees in relation to potassium and calcium nutrition. Tree Physiol 2010;30(9):1140-7.

Gandois L, Nicolas M, VanderHeijden G, Probst A. The importance of biomass net uptake for a trace metal budget in a forest stand in north-eastern France. Sci Total Environ 2010a; 408(23):5870-7.

Gandois L, Tipping E, Dumat C, Probst A. Canopy influence on trace metal atmospheric inputs on forest ecosystems: speciation in throughfall. Atmos Environ 2010b;44(6): 824-33.

Garnaud S, Mouchel J-M, Chebbo G, Thévenot DR. Heavy metal concentrations in dry and wet atmospheric deposits in Paris district: comparison with urban runoff. Sci Total Environ 1999;235(1-3):235-45.

Garty J. Biomonitoring atmospheric heavy metals with lichens: theory and application. Crit Rev Plant Sci 2001;20(4):309-71.

Goldschmidt VM. The principles of distribution of chemical elements in minerals and rocks. J Chem Soc 1937:655-73.

Gromet LP, Silver LT. Rare earth element distributions among minerals in a granodiorite and their petrogenetic implications. Geochim Cosmochim Acta 1983:47(5):925-39.

Harmens H, Norris DA, Steinnes E, Kubin E, Piispanen J, Alber R, et al. Mosses as biomonitors of atmospheric heavy metal deposition: spatial patterns and temporal trends in Europe. Environ Pollut 2010;158(10):3144-56.

Hawksworth DL, Rose F. Qualitative scale for estimating sulphur dioxide air pollution in England and Wales using epiphytic lichens. Nature 1970;227:145-8.

Heaton RW, Rahn KA, Lowenthal DH. Determination of trace-elements, including regional tracers, in Rhode-Island precipitation. Atmos Environ A Gen Top 1990;24(1):147-53. Henderson P. Rare earth element geochemistry. Amsterdam: Elsevier; 1984.

Hernandez L, Probst A, Probst JL, Ulrich E. Heavy metal distribution in some French forest soils: evidence for atmospheric contamination. Sci Total Environ 2003;312(1-3): 195-219.

Ichihashi H, Morita H, Tatsukawa R. Rare earth elements (REEs) in naturally grown plants in relation to their variation in soils. Environ Pollut 1992;76(2):157-62.

Knappe A, Möller P, Dulski P, Pekdeger A. Positive gadolinium anomaly in surface water and ground water of the urban area Berlin, Germany. Chem Erde Geochem 2005 65(2):167-89

Koeppenkastrop D, Decarlo EH, Roth M. A method to investigate the interaction of rare earth elements in aqueous solution with metal oxides. J Radioanal Nucl Chem Artic 1991;152(2):337-46.

Kümmerer K, Helmers E. Hospital effluents as a source of gadolinium in the aquatic environment. Environ Sci Technol 2000;34(4):573-7.

Laveuf C, Cornu S. A review on the potentiality of Rare Earth Elements to trace pedogenetic processes. Geoderma 2009;154(1-2):1-12.

Loppi S, Nelli L, Ancora S, Bargagli R. Passive monitoring of trace elements by means of tree leaves, epiphytic lichens and bark substrate. Environ Monit Assess 1997;45(1): $81-8$

Markert B, de Li Z. Inorganic chemical investigations in the forest biosphere reserve near Kalinin, USSR - II. The distribution of lanthanide elements in the vegetation cover. Vegetation 1991:97(1):57-62.

Markert B, Breure AM, Zechmeister HG. Bioindicators and biomonitors: principles, concepts and applications. Kidlington: Elsevier; 2003.

Miao L, Xu R, Ma Y, Zhu Z, Wang J, Cai R, et al. Geochemistry and biogeochemistry of rare earth elements in a surface environment (soil and plant) in South China. Environ Geol 2008;56:225-35.

Natelhoffer KJ, Fry B. Controls on natural nitrogen-15 and carbon-13 abundances in forest soil organic matter. Soil Sci Soc Am J 1988;52(6):1633-40.

Nieboer E, Richardson DHS, Tomassini FD. Mineral uptake and release by lichens overview. Bryologist 1978;81(2):226-46.

Nilsson J, Grennfelt P. Critical loads for sulphur and nitrogen. Report from a workshop held at Skokloster, Sweden, 19-24 March 1988. Copenhagen: Nordic Council of Ministers; 1988

Pang X, Li D, Peng A. Application of rare-earth elements in the agriculture of China and its environmental behavior in soil. Environ Sci Pollut Res 2002;9(2):143-8.

Plank T, Langmuir $\mathrm{CH}$. The chemical composition of subducting sediment and its consequences for the crust and mantle. Chem Geol 1998;145(3-4):325-94.

Prussia CM, Killingbeck KT. Concentrations of ten elements in two common foliose lichens - leachability, seasonality, and the influence of rock and tree bark substrates. Bryologist 1991:94(2):135-42.

Rabiet M, Brissaud F, Seidel JL, Pistre S, Elbaz-Poulichet F. Positive gadolinium anomalies in wastewater treatment plant effluents and aquatic environment in the Hérault watershed (South France). Chemosphere 2009;75(8):1057-64.

Rauch JN, Pacyna JM. Earth's global Ag, Al, Cr, $\mathrm{Cu}, \mathrm{Fe}, \mathrm{Ni}, \mathrm{Pb}$, and $\mathrm{Zn}$ cycles. Global Biogeochem Cycles 2009;23. [16 pp.]

Richardson DHS. Pollution monitoring with lichens. Naturalists' handbook series. Slough: The Richmond Publishing Co. Ltd.; 1992.

Rosman K, Chisholm W, Boutron C, Candelone J, Patterson C. Anthropogenic lead isotopes in Antarctica. Geophys Res Lett 1994;21(24):2669-72. 
Rühling A, Tyler G. An ecological approach to the lead problem. Bot Notiser 1968;121(3): 321-42.

Rusu AM. Sample preparation of lichens for elemental analysis. In: Nimis PL, Scheidegge C, Wolseley PA, editors. Monitoring with Lichens - Monitoring Lichens. Earth and environmental sciencesDordrecht: Kluwer/NATO Science Series; 2002. p. 305-9.

Rusu AM, Chimonides PDJ, Jones GC, Garcia-Sanchez R, Purvis OW. Multi-element including rare earth content of lichens, bark, soils, and waste following industrial closure. Environ Sci Technol 2006;40(15):4599-604.

Sholkovitz ER. The aquatic chemistry of rare earth elements in rivers and estuaries. Aquat Geochem 1995:1:1-34.

Spickova J, Navratil T, Rohovec J, Mihaljevic M, Kubinova P, Minarik L, et al. Positive gadolinium anomalies in wastewater treatment plant effluents and aquatic environment in the Hérault watershed (South France). Geochem Explor Environ Anal 2010;10: 383-90.

Steinmann M, Stille P. Controls on transport and fractionation of the rare earth elements in stream water of a mixed basaltic-granitic catchment basin (Massif Central, France). Chem Geol 2008;254(1-2):1-18.

Stille P, Steinmann M, Pierret M-C, Gauthier-Lafaye F, Chabaux F, Viville D, et al. The impact of vegetation on REE fractionation in stream waters of a small forested catchment (the Strengbach case). Geochim Cosmochim Acta 2006:70(13):3217-30.

Stille P, Pierret M-C, Steinmann M, Chabaux F, Boutin R, Aubert D, et al. Impact of atmospheric deposition, biogeochemical cycling and water-mineral interaction on REE fractionation in acidic surface soils and soil water (the Strengbach case). Chem Geol 2009;264(1-4):173-86

Sugimae A. Atmospheric concentrations and sources of rare earth elements in the Osaka area, Japan. Atmos Environ 1980;14(10):1171-5. [1967].

Suzuki Y, Hikida S, Furuta N. Cycling of rare earth elements in the atmosphere in central Tokyo. J Environ Monit 2011;13(12):3420-8.
Swieboda M, Kalemba A. The lichen Parmelia physodes (L.) Ach. as indicator for determination of the degree of atmospheric air pollution in the area contaminated by fluorine and sulphur dioxide emission. Acta Soc Bot Pol 1978;47(1-2):25-40.

Szczepaniak K, Biziuk M. Aspects of the biomonitoring studies using mosses and lichens as indicators of metal pollution. Environ Res 2003;93(3):221-30.

Taylor SR. Basaltic volcanism. In: Taylor SR, editor. Planetary science: a lunar perspective, vol. 6. Houston: Lunar and Planetary Institute; 1982. p. 263-342.

Taylor SR, McLennan SM. The continental crust: its composition and evolution. Oxford: Blackwell; 1985

Tricca A, Stille P, Steinmann M, Kiefel B, Samuel J, Eikenberg J. Rare earth elements and Sr and $\mathrm{Nd}$ isotopic compositions of dissolved and suspended loads from small river systems in the Vosges mountains (France), the river Rhine and groundwater. Chem Geol 1999;160(1-2):139-58.

Tyler G. Rare earth elements in soil and plant systems - a review. Plant and Soil 2004; 267(1-2):191-206.

Ulrich B, Pankrath J. Effects of accumulation of air pollutants in forest ecosystems. Dordrecht: Springer; 1983.

Weill DF, Drake MJ. Europium anomaly in plagioclase feldspar: experimental results and semiquantitative model. Science 1973:180(4090):1059-60.

Wolff E, Suttie E, Peel D. Antarctic snow record of cadmium, copper, and zinc content during the twentieth century. Atmos Environ 1999;33(10):1535-41.

Wolterbeek B. Biomonitoring of trace element air pollution: principles, possibilities and perspectives. Environ Pollut 2002;120(1):11-21.

Zeng F, Tian $\mathrm{H}$, Wang Z, An Y, Gao F, Zhang L, et al. Effect of rare earth element europium on amaranthin synthesis in Amarathus caudatus seedlings. Biol Trace Elem Res 2003; 93(1-3):271-82.

Zhang J, Liu C-Q. Major and rare earth elements in rainwaters from Japan and East China Sea: natural and anthropogenic sources. Chem Geol 2004;209(3-4):315-26. 